\title{
Security policy of the Slovak Republic in the context of intensifying the hybrid actions of the Russian Federation
}

\author{
Maksymets V. Y., Lviv Polytechnic National University
}

The article analyzes the changes in the security environment of Slovakia, which took place after the annexation of the Crimea and the situation in eastern Ukraine. This changed the strategic situation not only in Central and Eastern Europe, but de facto in the European and transatlantic defense complex. These strategic changes not only changed the existing situation that existed since the end of the Cold War, but led to a paradigm shift in security policy. Today, besides defense, citizens of Slovakia also define other vectors, in particular energy, ecological, and cybernetic. They are clearly international in nature, and therefore the Slovak foreign policy and diplomacy must take them into account more intensively than before, possibly to the detriment of other activities. In order to realize its security interests, the Slovak Republic uses its membership in international (NATO, UN) and regional (Visegrad Four, EU, OSCE) organizations and associations, developing its capabilities, flexibility, and mutually reinforcing cooperation. NATO membership is the determining factor in Slovak foreign security.

The benefits of this study are consideration of the issues of European security and its interconnectedness with the policy of the Slovak Republic is relevant and at the same time complicated. This is due to the transformation of the European security system and the security and foreign policy of Slovakia as a result of a number of factors.

First, the main factors determining the security of Central and Eastern Europe, as well as the security policy paradigm that existed in Europe since the end of the Cold War, have changed. The second important factor is Slovakia's response to these changes, because the foreign policy priorities of the country have not yet been determined. In this regard, in the formulation and implementation of the security policy of Slovakia in 2014, there was a period of systemic changes through the annexation by the Russian Federation of Crimea. The Ministry of Foreign and European Affairs of the Slovak Republic, on the one hand, sought to maintain the neutral nature of foreign policy, while the Ministry of Defense did not react to changes. The third factor, which is also closely related to others, is a difficult task, accordingly, to find consensus on the destruction of some of the key priorities of the foreign and security policy of Slovakia, which would lead to the adoption by the Ministry of Foreign Affairs and European Affairs of a comprehensive plan to counter foreign policy challenges, addressed to the Visegrad Four, the Eastern Partnership, the EU and NATO.

Keywords: foreign policy; Slovak Republic; Central and Eastern Europe; Ukrainian crisis; security

\section{Політика безпеки Словацької Республіки у контексті активізації гібридних дій Російської Федерації}

\section{Максимець В. Є., Національний університет «Львівська політехніка»}

Проаналізовано зміни в середовищі безпеки Словаччини, що відбулися після анексії Криму та ситуації на сході України. Це змінило стратегічну ситуацію не тільки в Центрально-Східній Свропі, але де-факто в європейському та трансатлантичному оборонному комплексі. Обгрунтовано тезу, що ці стратегічні зміни не тільки змінили ситуацію, яка існувала з кінця холодної війни, але призвели до зміни парадигми в політиці безпеки. Сьогодні, крім оборони громадяни Словаччини, визначають також інші вектори, зокрема енергетичний, екологічний, кібернетичний. Як у формулюванні так і у виконанні політики безпеки Словаччини у 2014 р. був період системних змін через анексію Російською Федерацією Криму. Для реалізації інтересів безпеки Словацька Республіка використовує своє членство в міжнародних (НАТО, ООН) і регіональних (Вишеградська четвірка, СС, ОБСС) організаціях та об'єднаннях, розвиваючи свої здібності, гнучкість і їх взаємно посилюючу співпрацю. Визначальним у словацькій зовнішній безпеці виступає членство в НАТО.

Ключові слова: зовнішня політика; Словацька Республіка; Центрально-Східна Свропа; українська криза; безпека

\section{Политика безопасности Словацкой Республики в контексте активизации гибридных действий Российской Федерации}

\section{Максимець В. Е., Национальный университет «Львовская политехника»}

Проанализированы изменения в среде безопасности Словакии, произошедшие после аннексии Крыма и ситуации на востоке Украины. Это изменило стратегическую ситуацию не только в Центрально-Восточной Европе, но де-факто в европейском и трансатлантическом оборонном комплексе. Обоснованный тезис, что эти стратегические изменения не только изменили ситуацию, которая существовала с конца холодной войны, но привели к изменению парадигмы в политике безопасности. Сегодня, кроме обороны граждане Словакии, определяют также 
другие векторы, в частности энергетический, экологический, кибернетический. Как в формулировке, так и в исполнении политики безопасности Словакии в 2014 был период системных изменений из-за аннексии Российской Федерацией Крыма. Для реализации интересов безопасности Словацкая Республика использует свое членство в международных (НАТО, ООН) и региональных (Вышеградская четверка, ЕС, ОБСЕ) организациях и объединениях, развивая свои способности, гибкость, и их взаимно усиливающее сотрудничество. Определяющим в словацкой внешней безопасности выступает членство в НАТО.

Ключевые слова: внешняя политика; Словацкая Республика; Центрально-Восточная Европа; украинский кризис; безопасность

\section{Problem statement.}

A $t$ the end of the Cold War, as in previous times, security continues to be seen as the main problem of international politics, as a prerequisite for successful solution of other problems, including global. However, the perspective differ primarily of going beyond the limits of the concept of «national security», previously seen mainly in its military-political dimension. Continuity is found in the uncertainty of international legal subjectivity role and status of many countries, the absolute efficacy of unilateral action and new endless debates about the ethical principles of foreign policy.

The annexation of Crimea sets a very dangerous precedent for the future security environment in Europe, and in post-Soviet space especially. The Ukrainian conflict has also exposed weaknesses in international law, agreements and treaties, as these often allow for contradictory interpretations. The factors and potential negative consequences of forces imbalance are identified not only in Central and Eastern Europe, but also in the global arena in general.

\section{Analysis of studies and publications.}

The problem of the development of political international relations of the countries of Central and Eastern Europe in the post-communist period is covered in numerous scientific works, publications, monographs. The specifics of Slovakia is that most of the publications are carried out by experts from independent research centers and non-governmental organizations of the Slovak Republic. Among the Slovak scholars, politicians and publicists, the main place is occupied by the scholars from the nongovernmental scientific-analytical research center of the Slovak Foreign Policy Association such as S. Goda, O. Gyarfashova, A. Duleba, Y. Marusyak, G. Mesezhnikov, R. Ondreychak, D. Fischer.

An analysis of recent research and publications on this issue suggests that it is the subject of research by many Ukrainian scholars. Among domestic researchers of transformations and institutional foundations of national minority policies during the period of postcommunist transformation in Central and Eastern Europe and Slovakia in particular, it is necessary to identify such scholars as V. Andreiko, S. Vidnyansky, G. Gaitanzhy, N. Lazar, M. Landeel, S. Mitryayev, G. Perepelytsya, V. Prikhodko, I. Syuska, L. Yanchuk and others.

The purpose of the study is to investigate the current state of foreign policy of the Slovak Republic and to analyze the fundamental principles and interests of Slovakia in the field of security policy.

\section{Essential material.}

The Slovak Republic is geographically, historically, culturally, politically and economically linked to the Euro-Atlantic area. Individually or in cooperation with other countries and international organizations, defends and defends freedom, democracy, the rule of law and human rights in accordance with the principles of the UN Charter and other norms of international law. The Slovak Republic defends the values of freedom, peace, democracy, rule of law, justice, pluralism, solidarity and human rights and fundamental freedoms. Carries out security policy in order to guarantee the necessary level of security of the citizen and the state.

In preserving its security interests, the Slovak Republic exercises its sovereign right to guarantee its security, based on the right of individual and collective self-defense in accordance with the UN Charter. In order to achieve this, Slovakia follows the following principles: the sovereign right to ensure the safety of citizens and the state; the right to individual and collective self-defense; indivisibility of security; solidarity and commitment; prevention of potential threats and conflicts; giving priority to peaceful means of resolving conflicts; effective functioning of international standards; coordination of joint actions by the international community; a comprehensive approach to ensuring the security of citizens and the state; use of all available national and international documents and facilities in accordance with the law and obligations; trust in the state in the system of international relations and security; awareness and active participation of citizens [2].

The Common Security and Defence Policy (CSDP), as an integral part of the Common Foreign and Security Policy (CFSP), is a crisis management instrument belonging to the sphere of intergovernmental activities of the EU. CSDP provides the EU with operational capacity based on civilian and military resources to carry out peacekeeping missions outside its territory, prevent conflicts and strengthen international security. Along with the UN and NATO it constitutes a preferred multinational framework for external peacekeeping operations.

The interests of Slovakia's security, based on the common values and needs of their 
citizens and state, are:

- providing security of citizens and protecting their human rights and fundamental freedoms;

- guaranteeing territorial integrity, sovereignty, inviolability of borders, political independence and identity;

- the development of a democratic state, a constitution, the rule of law and a market economy;

- creation of conditions for sustainable economic, social, ecological and cultural development of society;

- strengthening of strategic transatlantic partnership, joint security of allies;

- increasing the efficiency of international organizations in which Slovakia is a member and support of the enlargement of NATO and the EU;

- development of good partnership relations and all forms of mutually beneficial cooperation with the countries with which Slovakia has common interests;

- promoting the consolidation and expansion of freedom and democracy, respect for human rights, the rule of law, international law, peace and stability in the world [8].

In order to realize its security interests, the Slovak Republic uses its membership in international and regional organizations and associations, developing its capabilities, flexibility, and mutually reinforcing cooperation.

Slovakia's membership in the United Nations, the OSCE and other organizations and structures of a particular region actively contributes to the efforts of the international community to maintain peace and security in the world. By joining NATO, the Slovak Republic has become part of collective defense and security as a basis for transatlantic security and stability, and its security is guaranteed by allied commitments. As a member of the EU, Slovakia has received guarantees of political and economic stability, as well as the opportunity to take an active part in the development, implementation and strengthening of overall security and defense policy within the framework of the common foreign and security policy.

As noted by L. Chekalenko, the leveling of the previous system of security has led to uncontrolled chaos, to the destruction of human lives, economic potential, to the disaster of civilizations. On the agenda came the Russian factor of influence, which began a new round of repartition of the world. It should be noted that Russia took advantage of the current situation: the weakening of the European security factor, the deep dependence of European integration on Russian raw materials resources, on the one hand. On the other hand, the gradual removal of the American factor from European processes, enshrined in the US state strategy for the near future, is an American node of unrealized geostrategic interests in the Middle East and Africa, in which the US, to put it mildly, is stuck [1].

However, as evidenced by the destabilization of the ethno-political situation in Ukraine in 20142015, which led to an ethnic-political conflict with the participation of a neighboring state, the Russian Federation should always take into account the conflictual potential of ethnicity, which in certain circumstances may overcome the constructive interaction of various ethnic communities and provoke ethnic instability in some regions and states in general. The annexation of the Crimea, the situation in the east of Ukraine brought fundamental changes in the security environment of Slovakia, which changed the strategic situation not only in Central and Eastern Europe, but de facto in the European and transatlantic defense complex. These strategic changes not only changed the existing situation that existed since the end of the Cold War, but led to a paradigm shift in security policy.

As already noted, membership in NATO plays a decisive role in Slovak foreign security. As a result of the Ukrainian crisis, and the spread of instability on the southern borders of NATO and the Middle East, the Alliance has taken steps to increase its defense capability. NATO Summit in Wales in September 2014 adopted an action plan for readiness, supported by Slovakia. In this context, the Slovaks are committed to stop reducing defense expenditures and to ensure their real growth in line with economic growth, while in 2020 it will allocate $1.6 \%$ of GDP to defense. Slovakia presented a plan to spend $20 \%$ of defense spending on modernization of the armed forces in 2016 [5].

Today, besides the defense of Slovaks, other vectors are determined, including energy, ecological, and cybernetic. They are clearly international in nature, and therefore the Slovak foreign policy and diplomacy must take them into account more intensively than before, possibly to the detriment of other activities.

M. Laichak believes that there is a security issue in the so-called frozen conflicts. In Europe, in particular in Transnistria, Abkhazia, South Ossetia, Nagorny Karabakh, Northern Cyprus, in some respects Kosovo. Also M. Laichak claims that, perhaps, Crimea and perhaps Donetsk and Luhansk regions should be included here. The first four conflicts are not considered by the Slovaks directly, but are carefully observed. The opening of the Slovak embassy in Tbilisi in 2014 contributes to the more balanced position of Abkhazia and South Ossetia, which Slovakia uses to «cover» only from Moscow. As far as Northern Cyprus is concerned, in 2014, Slovaks continued to promote dialogue between hostile communities through meetings of their representatives on the grounds of the Slovakian embassy in Nicosia. According to M. Laychak, this 
is a good example and an approach to international problems - diplomacy should be able to live and work [7, p. 15-16].

The Russian-Ukrainian war has long been a priority theme for social and political discourse in Slovakia in the field of security and defense. The Slovaks believe that a similar situation occurred about ten years ago, in 2003, in connection with the war in Iraq and in comparison with Iraq, the current situation is more serious because the war takes place in the immediate vicinity of Slovakia and directly threatens the security of Central -East region.

O. Gyarfashova emphasizes that the discussion of the Russo-Ukrainian conflict in Slovakia was focused on the following issues: the description and characteristics of the conflict (description of the events of the «Russian-Ukrainian war» against the «civil war in Ukraine»), whether there are Russian armed forces, whether they are directly involved in operations in Ukraine or not, should the same line be retained as in the Slovak strategic security policy partners (USA, Germany, Poland), and what consequences will it have for Ukraine's potential integration ambitions for joining the ATO and what this will mean for Slovakia [6].

The polarity in the positions here appears in the reverse order. The president of the Slovak Republic, Andrei Kisk, is definitely pro-Ukrainian and proWestern. He fully supports the sanctions regime introduced by the European Union, advocating for NATO's defense capabilities, including the Visegrad countries, including Slovakia.

In connection with the presidency of Slovakia in the Visegrad Quartet (2014-2015), A. Kisk invited the Ukrainian President P. Poroshenko to take part in the Visegrad Group summit in Germany. Such an initiative by the Slovak president is undoubtedly a signal of the awareness of the need to strengthen the interaction between the Central European countries, Ukraine and Germany in the face of the challenge that the current Russian authorities threw at the united Europe.

Unlike the Slovak president, Slovak Prime Minister R. Fico defines his attitude to the RussianUkrainian conflict and European sanctions against Russia in another coordinate system. For him, judging by his statements, other factors than the common European values and the principle of inviolability of the borders east of Slovakia itself are important (good, its borders are securely protected as a result of membership in NATO and the EU). Economics, above all, can be generalized to express the essence of his views on how to respond to events in the east of Ukraine. The main thing is that Slovakia should continuously receive Russian gas and oil, and that in Russia it would be easy to sell cars produced in Slovakia. Obviously, it is precisely here that the reasons for Mr Fito's statements are about the absurdity of European sanctions, their criticism of Ukraine as a country, allegedly incapable of solving their own internal problems and problems that arise in relations with other states [4, p. 33].

The pro-Russian bias in the system of G. Fitzo's views on international relations has been notable for a long time. This Slovak politician never particularly concealed his personal sympathy for Putin, calling him a man who turned national pride into Russian people. Now, however, taking into account what has happened and still occurs in Ukraine, Crimea and eastern Ukraine, when the Russian president violates the fundamental principles of international law, R. Fito is no longer profitable to praise Putin, which is called an open text. However, he does not lose the opportunity to speak critically about the attitude of sanctions imposed by Europe. However, it does not proactively put the issue of cancellation or mitigation into the agenda of the EU, realizing that the chances of such a decision simply do not exist at the moment.

A. Duleba assesses NATO's role in the current crisis. On the one hand, most of the Slovak public agrees that NATO is the guarantor of the security of the Slovak Republic, is obliged to take part in collective defense in the event of an attack on NATO members and that, in the context of Russia's military aggression against Ukraine, NATO's presence in Central and Eastern Europe should be increased, but on the other hand, the apparent majority of the Slovak public are opposed to the presence of infrastructure in Slovakia [3].

The fundamental principles and interests of Slovakia in the field of security policy, including support for the integration ambitions of Ukraine and the Western Balkans, in 2014, formed a broad political and expert consensus (in relation to Ukraine). This fact is also recognized as an official document of the Ministry of Foreign Affairs and European Affairs on the external European policy in 2015 [10]. Although the political debate on the involvement of Russian troops in the conflict can be classified as irrelevant for public discourse, even from the point of view of the so-called information warfare, the question of the future of Ukraine, especially in the context of its integration ambitions, is absolutely crucial strategic issues in the security policy of Slovakia.

Still, all relevant parliamentary parties, regardless of their political significance, as well as the broad consensus of the community of experts, agreed that the main strategic goal was to support Slovakia's integration efforts and ambitions of the Western Balkan states and Ukraine, including support for membership in the European Union and NATO. This consensus was based on the idea that Central and Eastern Europe is the only security complex with Ukraine and this region can not be safe without 
stability, security and development of the Slovak largest neighbor, and without its membership in the same structure as Slovakia.

This consensus was officially announced in the Security Strategy, which states that «Slovakia will continue to perceive NATO enlargement, strengthening the zone of security and stability in the Euro-Atlantic»». The program declaration states that «the government will actively pursue an open door policy as a means to expand the zone of security and stability» [9], which de facto means unequivocal support for the further expansion of the Alliance.

\section{Conclusions.}

2014 has become a turning point in Slovak security policy for several reasons. First, the main factors determining the security of Central and Eastern Europe, as well as the security policy paradigm that existed in Europe since the end of the Cold War, have changed. In addition to military-technical, legal and political changes that were characterized by the most important factor at the strategic level, Russia revives the political will to conduct military operations in Europe in order to achieve political or strategic goals. This situation has also affected the wider context of security, including NATO-Russia relations, which are crucial for Slovakia in shaping security policy. The change that can be described as a transition from Russia's «strategic partner» to a «strategic competitor» is a determining factor affecting Slovak security, at least in the long term, decades, but probably more.

The second important factor is Slovakia's response to these changes. In this regard, in 2014 there was a period of systemic changes, both in the formulation and in the implementation of the security policy of Slovakia. The Ministry of Foreign Affairs and European Affairs, on the one hand, sought to maintain the neutral nature of foreign policy, while the Ministry of Defense did not respond to changes.

\section{БІБІЛІОГРАФІЧНІ ПОСИЛАННЯ}

1. Чекаленко Л. Європа. Безпека. Україна. Дипломатія / Л. Чекаленко. - Режим доступу: http://lyudmilache.at.ua/ blog/evropa_bezpeka_ukrajina_diplomatija/2014-11-29-12

2. Bezpečnostná politika Slovennskej republiky // Ministerstvo zahraničných vecí a európskych záležitostí Slovenskej republiky. - Режим доступу: https://www.mzv.sk/zahranicna_politika/bezpecnostna_politika-uvod

3. Duleba A. Kríza na Ukrajine ako impulz pre východnú politiku SR a EÚ / A. Duleba // Výskumné centrum Slovenskej spoločnosti pre zahraničnú politiku. - Режим доступу: http:/www.sfpa.sk/wp-content/uploads/2015/09/A09.pdf

4. Duleba A. Twenty years of Slovak foreign policy: teething problems, successful integration and post-accession challenges / A. Duleba // International Issues \& Slovak Foreign Policy Affairs. - 2012. -Vol. XXI - № 3-4. - P. 25-64. 5. Gyárfášová O. Desat’ rokov v euroatlantickom priestore: obraz verejnej mienky / O. Gyárfášová // Ročenka zahraničnej politiky Slovenskej Republiky 2014, Výskumné centrum slovenskej spoločnosti pre zahraničnú politiku, N.O. - Bratislava, 2015 - P. 141-153.

6. Gyárfášová O. Rusko-ukrajinská kríza ako obraz slovenskej spoločnosti [Електронний pecypc] / O. Gyárfášová // Zahranicna politika. - Режим доступу: www.zahranicnapolitika.sk/rusko-ukrajinska-kriza-ako-obraz-slovenskejspolocnosti/

7. Lajčák M. Slovensko, európa, svet / M. Lajč́k // Ročenka zahraničnej politiky Slovenskej Republiky 2014, Výskumné centrum slovenskej spoločnosti pre zahraničnú politiku, N.O. - Bratislava, 2015 - P. 9-17.

8. Slovensko a Spoločná bezpečnostná a obranná politika ЕÚ [Електронний pecypc] / Ministerstvo zahraničných vecí a európskych záležitostí Slovenskej republiky. - Режим доступу: https://www.mzv.sk/zahranicna_politika/bezpecnostna politika-rt_slovensko_a_spolocna_bezpecnostna_a_obranna_politika_eu

9. Stratégia MZV SR - Úspešné Slovensko v bezpečnom svete - Режим доступу: https://www.mzv.sk/ documents/10182/621898/Strategia+MZV+definit+260208.pdf

10. Strednodobá stratégia zahraničnej politiky Slovenskej republiky do r. 2015 // Ministerstvo zahraničných vecí a európskych záležitostí Slovenskej republiky. - Режим доступу: https://www.mzv.sk/documents/10182/621946/ strategia+ZP+SR.pdf

\section{REFERENCES}

1. Chekalenkoб L. Yevropa. Bezpeka. Ukrayina. Dyplomatiya [Europe. Security. Ukraine]. Retrieved from: http:// lyudmilache.at.ua/blog/evropa_bezpeka_ukrajina_diplomatija/2014-11-29-12 [in Ukrainian].

2. Polityka bezpeky Slovats'koyi Respubliky [Security Policy of the Slovak Republic]. Ministerstvo zakordonnykh sprav ta yevropeys'kykh sprav Slovats'koyi Respubliky. Retrieved from: https://www.mzv.sk/zahranicna_politika/bezpecnostna_ politika-uvod [in Slovak].

3. Duleba, A. Kryza v Ukrayini yak impul's dlya skhidnoyi polityky SR ta EU [The crisis in Ukraine as an impetus for the Eastern policy of the Slovak Republic and the EU]. Naukovyy tsentr Slovats'koho tovarystva zovnishn'oyi polityky. Retrieved from: http://www.sfpa.sk/wp-content/uploads/2015/09/A09.pdf [in Slovak].

4. Duleba, A. (2012). Twenty years of Slovak foreign policy: teething problems, successful integration and postaccession challenges: International Issues \& Slovak Foreign Policy Affairs. 
5. Gyárfášová, O. (2015). Desyat' rokiv u Yevroatlantychnomu rehioni: znimok hromads'koyi dumky [Ten Years in the Euro-Atlantic Area: A Picture of Public Opinion]. Shchorichnyk zovnishn'oyi polityky Slovats'koyi Respubliky 2014, Doslidnyts'kyy tsentr Slovats'koho tovarystva zovnishn'oyi polityky, N.O. Bratyslava. 141-153 [in Slovak].

6. Hyarfashova, O. Rosiys'ko-ukrayins'ka kryza yak kartyna slovats'koho suspil'stva [Russia-Ukrainian crisis as a picture of Slovak society]. Zovnishnya polityka. Access mode: www.zahranicnapolitika.sk/rusko-ukrajinska-kriza-ako-obrazslovenskej-spolocnosti/ [in Slovak].

7. Laychak, M. (2015). Slovachchyna, Yevropa, Svit (2014) [Slovakia, Europe, the World (2014)] Shchorichnyk zovnishn'oyi polityky Slovats'koyi Respubliky 2014, Doslidnyts'kyy tsentr Slovats'koho tovarystva zovnishn'oyi polityky, N.O. Bratyslava. 9-17 [in Slovak].

8. Slovachchyna ta Spil'na polityka bezpeky ta oborony EU [Slovakia and the Common Security and Defense Policy of the EU]. Ministerstvo zakordonnykh sprav ta yevropeys'kykh sprav Slovats'koyi Respubliky. Retrieved from: https://www. mzv.sk/zahranicna_politika/bezpecnostna_politika-rt_slovensko_a_spolocna_bezpecnostna_a_obranna_politika_eu [in Slovak].

9. Stratehiya MZS SR - uspishna Slovachchyna v bezpechnomu sviti [The Strategy of the MFA SR - Successful Slovakia in a Safe World]. Retrieved from: https://www.mzv.sk/documents/10182/621898/Strategia+MZV+definit+260208.pdf [in Slovak].

10. Seredn'ostrokova stratehiya zovnishn'oyi polityky Slovats'koyi Respubliky do r. 2015 [Medium-term Strategy of the Foreign Policy of the Slovak Republic till r. 2015]. Ministerstvo zakordonnykh sprav ta yevropeys'kykh sprav Slovats'koyi Respubliky. Retrieved from: https://www.mzv.sk/documents/10182/621946/strategia+ZP+SR.pdf [in Slovak].

\section{Maksymets Vira}

Ph.D.

Lviv Polytechnic National University

79000, Lviv, st. St. Bandery, 12

\section{МаксимецьВіра Свгенівна}

Кандитат політичних наук

Національний університет «Львівська політехніка»

79000, Львів, вул. Степана Бандери, 12

Email: maksymetsvira@ukr.net

Цитування: Максимець В. Є. Політика безпеки Словацької Республіки у контексті активізації гібридних дій Російської Федерації / В. Є. Максимець // Науково-теоретичний альманах «Грані». - 2018. T. 21. - № 3. - С. 76-81.

Citation: Maksymets, V.Y. (2018). Polityka bezpeky Slovatskoi Respubliky u konteksti aktyvizatsii hibrydnykh dii Rosiiskoi Federatsii [Security policy of the Slovak Republic in the context of intensifying the hybrid actions of the Russian Federation]. Scientific and theoretical almanac «Grani», 21(3), 76-81. 